\title{
Drive-by Photoscreening [Letter]
}

This article was published in the following Dove Press journal:

Clinical Ophthalmology

\section{David G Hunter (DD}

Boston Children's Hospital, Harvard Medical School, Boston, MA, USA
Correspondence: David G Hunter Email david.hunter@childrens.harvard.edu

\section{Dear editor}

In their article, "Drive-by Photoscreening," "Keffalos, Martin, and Arnold make impressive, hands-on efforts to modify vision screening devices to enable their continued use during a pandemic. I would like to offer two clarifications.

First, the authors state that they determined the devices were reliable for detecting amblyopia risk factors after modification, but the results indicate that the accuracy of all 3 devices was reduced compared with published values. This is especially true for the blinq ${ }^{\circledR}$ device. As one of the inventors of the blinq technology, I should point out that the device should not be used with any sort of light shield such as was used; these materials, though black, can reflect infrared light back into the device and confuse the circuitry. Fortunately, the design of blinq allows the patient and operator to stand several feet apart, there is no physical contact with the patient, and the test lasts only 2.5 to at most 10 seconds, thus making it suitable for use during a pandemic as long as proper masking protocols are followed.

Second, the article title refers to "photoscreening," and even though blinq mirrors photoscreeners as an instrument-based screening test that provides instant results, blinq was not designed to identify amblyopia risk factors such as refractive error (though it can identify most children who have significant refractive errors). Instead, the device conducts a functional binocular test that determines whether a child's eyes can work together. This test requires good cooperation from children, and recent studies indicate that a child with amblyopia and/or strabismus cannot falsely "pass" a blinq test. Implementing blinq in early childhood, following manufacturer instructions for use, can confirm that a child has achieved the ability to achieve binocular vision and depth perception.

I thank Dr. Arnold and his team at Alaska Blind Child Discovery for their ongoing efforts and for their commitment to implementing safe and effective pediatric vision screening that is available to all children regardless of circumstance.

\section{Disclosure}

Dr David G Hunter is a board member for and receives equity from Rebion, Inc. and Luminopia, Inc. In addition, Dr David G Hunter has a US Patent 7,959,292 with royalties paid. The author reports no other conflicts of interest in this communication.

\section{Reference}

1. Keffalos M, Martin S, Arnold R. Drive-by photoscreening: plusoptix, 2WIN and blinq amblyopia detection during the COVID-19 pandemic. Clin Ophthalmol. 2021;15:775-782. doi:10.2147/OPTH. S300871 
Dove Medical Press encourages responsible, free and frank academic debate. The content of the Clinical Ophthalmology 'letters to the editor' section does not necessarily represent the views of Dove Medical Press, its officers, agents, employees, related entities or the Clinical Ophthalmology editors. While all reasonable steps have been taken to confirm the content of each letter, Dove Medical Press accepts no liability in respect of the content of any letter, nor is it responsible for the content and accuracy of any letter to the editor

\section{Publish your work in this journal}

Clinical Ophthalmology is an international, peer-reviewed journal covering all subspecialties within ophthalmology. Key topics include: Optometry; Visual science; Pharmacology and drug therapy in eye diseases; Basic Sciences; Primary and Secondary eye care; Patient Safety and Quality of Care Improvements. This journal is indexed on PubMed

Submit your manuscript here: https://www.dovepress.com/clinical-ophthalmology-journal
Central and CAS, and is the official journal of The Society of Clinical Ophthalmology (SCO). The manuscript management system is completely online and includes a very quick and fair peer-review system, which is all easy to use. Visit http://www.dovepress.com/ testimonials.php to read real quotes from published authors. 